\title{
UTRICULARIA BREMII (LENTIBULARIACEAE) IN POLAND
}

\author{
Łukasz Krajewski ${ }^{1}$ \& Bartosz J. PŁachno
}

\begin{abstract}
Utricularia bremii Heer ex Kölliker has been found in a former sand quarry in Dąbrowa Górnicza (Silesia-Cracow Upland, S Poland). This subatlantic species is very rarely reported from Western and Southern Europe, and extremely rarely from Central Europe. Some localities were reported from Poland, mainly in the first half of the $20^{\text {th }}$ century, but none of them are considered reliable and the species is not included in the flora of Poland. In the newly discovered locality the species forms a very abundant population in shallow, nutrient-poor ditches and pools. The origin of the population is uncertain, but before sand exploitation started the area was covered by extensive fens.
\end{abstract}

Key words: distribution, ecology, Lentibulariaceae, Poland, Utricularia bremii

Eukasz Krajewski, Department of Nature Protection and Rural Landscape, Institute of Technology and Life Sciences, Falenty, Hrabska 3,05-090 Raszyn,Poland; e-mail: lukkrajewski@wp.pl

Bartosz J. Plachno, Department of Plant Cytology and Embryology, Jagiellonian University, Gronostajowa 9, 30-387 Kraków, Poland; e-mail: bartosz.plachno@uj.edu.pl

\section{INTRODUCTION}

The genus Utricularia L. is represented by 214 species (Taylor 1989). Five species have been documented from Poland so far: U. minor L., U. intermedia Hayne, U. ochroleuca R. W. Hartm., $U$. vulgaris $\mathrm{L}$. and $U$. australis $\mathrm{R}$. Br. (Mirek et al. 2002). Utricularia bremii Heer ex Kölliker was excluded as 'not occurring in Poland' (Żukowski 1974; Mirek et al. 2002).

Utricularia bremii was described by Heer from Katzensee Lake near Zurich on the basis of specimens collected by Jacob Bremi on June 26, 1836 (Heer in Kölliker 1839), and its presence at the locus classicus was confirmed at the end of the $20^{\text {th }}$ century (Käsermann \& Moser 1999). Utricularia bremii is a very rare species, reported from scattered localities in Central and Western Europe: Belgium, France, Switzerland, Italy, Germany, Denmark, the Czech Republic, Slovakia, Hungary, Romania and Ukraine (Taylor 1989; Beretta \& Tassara 2010; Vydrová et al. 2009; Beretta et al. 2011; Díte et al. 2013). Because the vegetative shoots of $U$. bremii are morphologically similar to the closely related $U$. minor (of

\footnotetext{
1 Corresponding author
}

which it was considered a subspecies or variety for a time), the two species have often been confused (Taylor 1989). Additionally, many historical records of $U$. bremii seem to be erroneous. Thus, the distribution and abundance of $U$. bremii are still not sufficiently recognized. For example, in the Czech Republic it was considered probably extinct but was recently rediscovered and is known from four localities (Vydrová et al. 2009; Adamec pers. comm. 2011).

Utricularia bremii has been reported from several localities in Poland: a few in Upper Lusatia Lubań ('Lauban'), Jędrzychowice ('Hennersdorf'), Mikułowa ('Nikolausdorf') (Schube 1903, 1904) and Czerna ('Tschirnewiese') near Węgliniec ('Kohlfurt') (Barber 1893); in the Lublin region in the Pojezierze Łęczyńsko-Włodawskie lake district, without a precise location (Fijałkowski 1960); in Pomerania at Chińskie Lake near Chojnice (Ławrynowicz 1965); and in Warmia between Lutry ('Lautern') and Wągsty ('Wangst') (Lettau 1911). However, the presence of $U$. bremii in the Polish flora has been questioned by Żukowski (1974) because the only existing herbarium specimens labeled as $U$. bremii, from Mikułowa 
(leg. C. Trautmann 1872, WRSL), represented $U$. minor, and none of the remaining historical records have been confirmed. Taylor (1989) did not mention the occurrence of $U$. bremii in Poland in his monograph of the genus Utricularia, and the species was not included in the Polish flora (Mirek et al. 2002).

In 2009, during a floristic investigation of the large Kuźnica Warężyńska sand quarry in Dąbrowa Górnicza, U. bremii was found in shallow pools and ditches by the first author.

\section{MATERIAL AND METHODS}

Utricularia bremii was found in an extensive $\left(\right.$ ca $\left.10 \mathrm{~km}^{2}\right)$ disused sand quarry in Dąbrowa Górnicza city in the central part of the Silesia-Cracow Upland (S Poland). The quarry is a vast, deep pit in which there is a lake having a surface area of $c a 5 \mathrm{~km}^{2}$. Field observations were made in 2009-2012. To describe the environmental characteristics of $U$. bremii, phytosociological relevés were made on standard plots covering $1 \mathrm{~m}^{2}$ each, and 33 of them were chosen for statistical analysis. Nomenclature follows Matuszkiewicz (2007) for syntaxa and mainly Mirek et al. (2002) for taxa.

Flowering shoots of $U$. bremii were collected and the flowers were fixed in $70 \%$ ethanol and later used for morphological analysis. The pollen grains were analyzed using light and scanning electron microscopy (HITACHI S-4700 SEM in the Scanning Microscopy Laboratory of Biological and Geological Sciences, Jagiellonian University, Kraków) at $20 \mathrm{kV}$. Voucher specimens are deposited in the herbarium of the Jagiellonian University (KRA). For comparison, additional fresh flowering material of $U$. minor was collected from the JeleniakMikuliny Nature Reserve near the town of Lubliniec. Flowering plants of $U$. bremii from the Czech Republic, kindly lent by Dr. Lubomir Adamec, were used for comparison with the Polish material.

\section{RESULTS AND DISCUSSION}

\section{Utricularia bremii Heer ex Kölliker}

Figs $1 \& 2$

Verz. Phan. Gew. Zürich: 142. 1839, and in Hegetschweiler, Fl. Schweiz: 384. 1840. - U. minor var. bremii (Heer) Franchet, Fl. Loir-et-Cher: 459. 1885. - U. minor subsp. bremii (Heer) Bertsch \& F. Bertsch, Fl. Württemburg \& Hohenzollern 386. 1948.
Morphologically, U. bremii is most similar to $U$. minor. The following features help distinguish these two species: shape of the lower lip of the flower, pollen grain morphology, and viable seeds.

Utricularia bremii (Fig. 1a-d) has an almost circular lower lip of the flower (sometimes wider than long), with lateral margins that are not bent down (Fig. 1a-c \& e). Utricularia minor has flowers with a lower lip longer than wide, with margins bent down (Fig. 1f). Most pollen grains produced by $U$. bremii are asymmetric and malformed (Fig. 1d), in contrast to U. minor which produces regular grains (for details see Beretta et al. 2014).

Utricularia bremii differs from $U$. minor in production of fruits. According to Casper and Manitz (1975), U. bremii is probably a male-sterile species. They observed the formation of micronuclei, micropollen, polyads and abortion of pollen. Likewise, Taylor (1989) did not record development of seeds in U. bremii, in agreement with our results. It was hypothesized that $U$. bremii might be a hybrid taxon (probable parents: $U$. minor, $U$. intermedia) but this should be confirmed using molecular techniques, as was done for $U$. australis (Kameyama et al. 2005). Utricularia australis is a sterile plant in Europe, not producing viable pollen grains and seeds. In contrast, microsporogenesis and pollen development typically occur in U. minor (Casper \& Manitz 1975) and this species produces seeds (Taylor 1989). However, there are two published records of fertile, seed-producing U. bremii (Rahmann et al. 2001; Adamec 2002). The specimens collected in Poland are identical with U. bremii from the Czech Republic, and their morphology fully corresponds with descriptions of the species by Taylor (1989) and Heer (in Kölliker 1839).

SPECIMENS EXAmined: POLAND, Silesia-Cracow UpLAND, Dąbrowa Górnicza, Kuźnica Warężyńska sand quarry, shallow ditch connected with excavation lake, $50^{\circ} 22^{\prime} 37^{\prime \prime} \mathrm{N}, 19^{\circ} 12^{\prime} 51^{\prime \prime} \mathrm{E}, 264 \mathrm{~m}$ a.s.l.; ditch adjacent to steep sand quarry margin, $50^{\circ} 23^{\prime} 45^{\prime \prime} \mathrm{N}, 19^{\circ} 13^{\prime} 27^{\prime \prime} \mathrm{E}$, 274 m a.s.1., 19 Sept. 2011, leg. E. Krajewski (KRA, dried flowering specimens and flowers in alcohol).

HaвiтAT. The species occurs in nutrient-poor (oligo-, mesotrophic), fully insolated areas with 

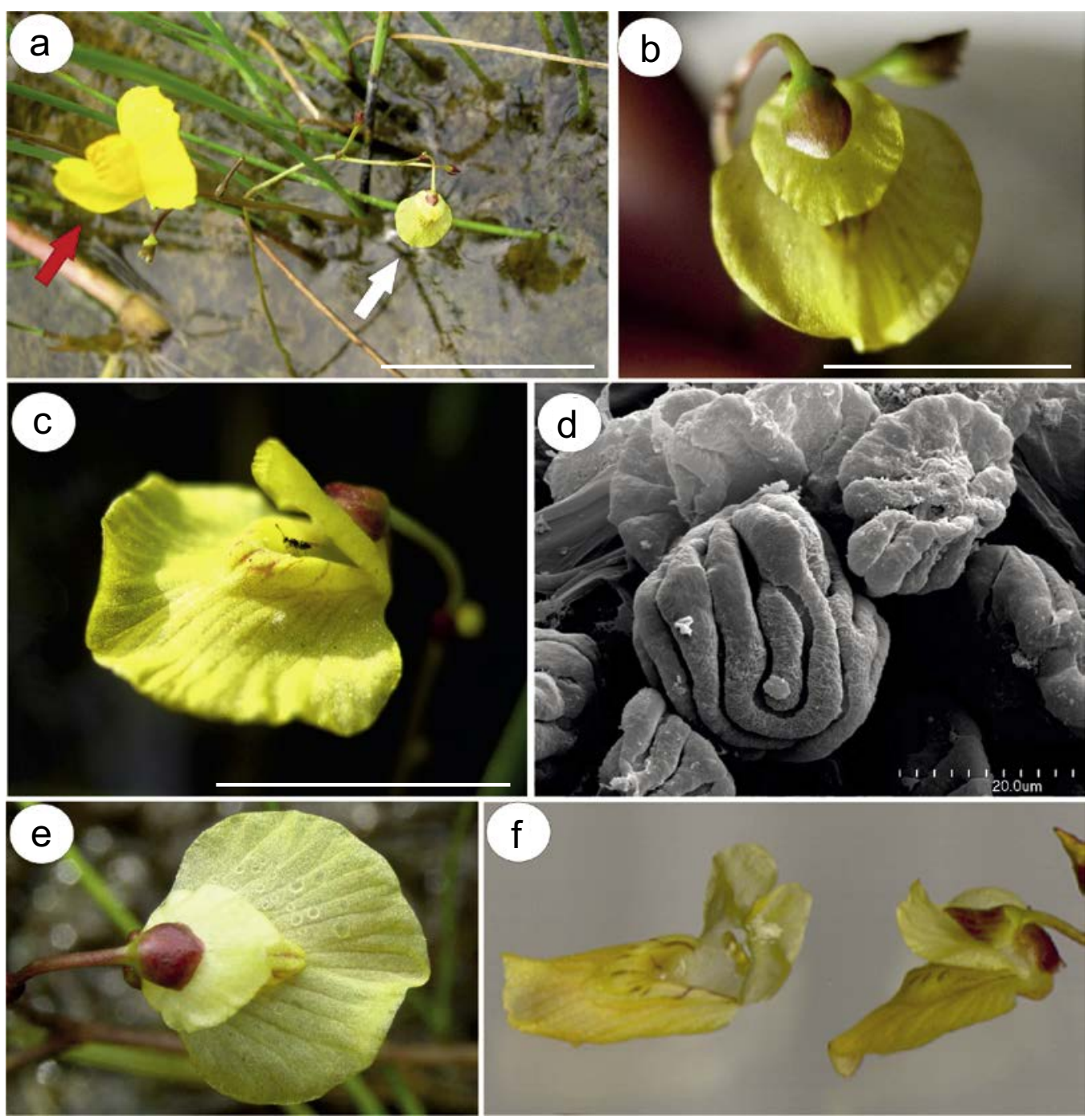

Fig. 1. a - Utricularia bremii Heer ex Kölliker (white arrow) and U. australis R. Br. (red arrow) in the Kuźnica Warężyńska sand quarry in Dąbrowa Górnicza. b \& c - Close-up of flowers of U. bremii from Kuźnica Warężyńska sand quarry (note almost circular flat lower lip). d - SEM micrograph of Utricularia bremii pollen grains. e - Flower of U. bremii from the Czech Republic. f - Flower of Utricularia minor L. with characteristic lateral margins of the lower lip curved downwards. Scale bars: $\mathrm{a}-5 \mathrm{~cm}$; b \& c - $1 \mathrm{~cm}$. Photo: Ł. Krajewski (a-c), B. J. Płachno (d) and L. Adamec (e \& f).

scattered vegetation. Utricularia bremii occurs at the bottom of the sand quarry in small water bodies (pools, ditches) fed by ferruginous groundwater. Utricularia bremii occurs abundantly, forming a population estimated at tens of thousands of shoots. It forms its own synusial aggregations in some places. Accompanying species represent several classes of vegetation:
Litorelletea uniflorae, Isoëto-Nanojuncetea, Scheuchzerio-Caricetea nigrae, Charetea, Potametea and Phragmitetea. However, three vegetation types were distinguished. The first group comprises shallow water bodies with Potamogeton gramineus, scattered Phragmites australis, Juncus bulbosus and Carex echinata. The second is a group of more species-rich patches 


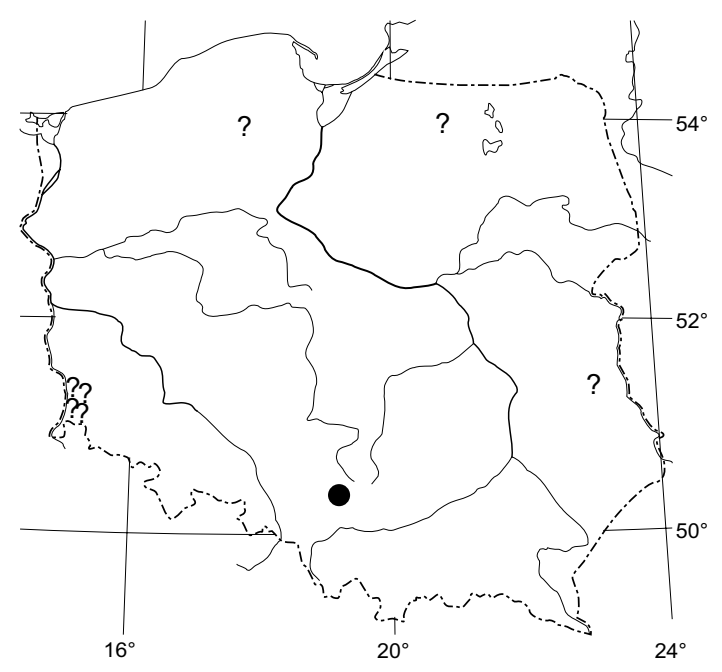

Fig. 2. Distribution of Utricularia bremii Heer ex Kölliker in Poland; - new locality, ? - doubtful locality from literature.

differentiated by common hydrophytes frequently found in eutrophic waters: Myriophyllum verticillatum, Potamogeton natans, Sparganium erectum, Lemna minor and Equisetum fluviatile. The third group is characterized by the presence of plants typical for mires and wet mineral sites (Drosera rotundifolia, Lycopodiella inundata, Carex viridula, Sphagnum fimbriatum). Utricularia bremii prefers periodically inundated, mineral-enriched sites, most often with very shallow water and an organic-mineral bottom. The following species have the highest constancy in phytosociological relevés with $U$. bremii: Phragmites australis (V), Salix rosmarinifolia (III), Juncus articulatus (II), J. bulbosus (II), J. effusus (II), Myriophyllum verticillatum (II) and Typha latifolia (II). In July 2011, U. bremii blossomed in trenches dug a year before near a stand of Cladium mariscus (sterile Utricularia minor recorded in phytosociological relevé of Cladietum marisci on June 28, 2009 (Krajewski 2011) in fact was $U$. bremii). In 2012, numerous $U$. bremii were also observed in shallow water of a large excavation lake in the Kuźnica Warężyńska sand quarry, called Pogoria IV (Fig. 1a). Among the scattered helophytes, $U$. bremii grew to $0.5 \mathrm{~m}$ water depth, together with Nitella syncarpa (Krajewski 2012), a rare subatlantic species endemic to Europe.
Utricularia bremii is a rare plant in the European flora, and a species with low competitive ability. It has disappeared from numerous historical locations due to extensive drainage of mires and increasing eutrophication. For example, it has completely disappeared from the Ukraine, where it was known from only a single record in Transcarpathia (Kish \& Danilik 2009). Hence it has been redlisted in Europe (Bilz et al. 2011).

The locality of $U$. bremii in Dąbrowa Górnicza is formally protected within the Nature 2000 Special Area of Conservation called Lipienniki w Dąbrowie Górniczej ('Fen Orchids in Dąbrowa Górnicza'). However, drainage is being done there, part of the area has recently been sold to a private investor despite the legal protection status, and the conservation perspectives for $U$. bremii are unfavorable.

It has been suggested that $U$. bremii and $U$. minor have similar ecological requirements (Moravec 1995), while U. minor and U. australis grow mainly in more alkaline and mineralrich habitats than $U$. ochroleuca and $U$. intermedia (Kosiba 2004; Dítě et al. 2006). Both in the Czech Republic and Dąbrowa Górnicza, $U$. bremii grows together with $U$. australis. The second species is ecologically very plastic and can grow in various types of artificial water reservoirs (Płachno 2008).

Acknowledgements. We are grateful to Dr. Lubomir Adamec (Institute of Botany, Academy of Sciences of the Czech Republic, Třeboň) for providing Bohemian material of Utricularia bremii for this study, Dr. Maciej Gąbka (Adam Mickiewicz University, Poznań) for statistical analyses and very helpful comments, and Dr. Paweł Pawlikowski (Warsaw University) for his careful reading and comments. We thank Mr. Krzysztof Ciesielski for drawing attention to $U$. minor with unusual flowers, photographed by the first author in Kuźnica Warężyńska, and for insisting that it really could be $U$. bremii. Bartosz J. Płachno gratefully acknowledges a Scholarship for Outstanding Young Scientists from the Minister of Science and Higher Education. Plant collection and morphological observations of protected plants were done in compliance with Polish law under permits nos. WPN.6402.166.2012.MS and OP-I.6400.42.2012.PWi.). 


\section{REFERENCES}

Adamec L. 2002. News and views. Carnivorous Plant Newsletter 31: 19.

BARBER E. 1893. Die Flora der Görlitzer Heide. Abhandlungen der Naturforschenden Gesellschaft zu Görlitz 20: 57-146.

Beretta M. \& Tassara F. 2010. Utricularia bremii Heer ex Kölliker. Inform. Bot. Ital. 42(2): 589-591.

Beretta M., Rodondi G., Adamec L. \& Andreis C. 2014. Pollen morphology of European bladderworts (Utricularia L., Lentibulariaceae) Rev. Palaeobot. Palynol. 205: 22-30.

Beretta M., Simonazzi M., Arrigoni P. \& Tassara F. 2011. New sites of Utricularia bremii Heer ex Kölliker (Lentibulariacae): considerations on its distribution and conservation in Italy. Inform. Bot. Ital. 43(1): 91-95 (in Italian with English summary).

Bilz M., Kell S. P., Maxted N. \& Lansdown V. 2011. European Red List of Vascular Plants. Publication Office of the European Union, Luxembourg.

Casper S. J. \& Manitz H. 1975. Beiträge zur Taxonomie und Chorologie der mitteleuropäischen Utricularia-Arten. 2. Androsporogenese, Chromosomen-zahlen und Pollenmorphologie. Feddes Repert. 86(4): 211-232.

DítĚ D., HrivnÁK R. \& Eliáš P. JUN. 2013. Utricularia bremii (Lentibulariaceae) rediscovered in Slovakia. Polish Bot. J. 58(2): 653-658.

DítĚ D., Navrátilová J., HáJeK M., Valachovič M. \& PUKAJOVÁ D. 2006. Habitat variability and classification of Utricularia communities: Comparison of peat depressions in Slovakia and the Trebon basin. Preslia 78: 331-343.

FiJAŁKowski D. 1960. The flora of Łęczna-Włodawa Lake District and adjacent peat bogs. Ann. Univ. Mariae CurieSkłodowska, Sect. B 14(3): 131-206 (in Polish with English summary).

KameyamaY., Toyama M. \& OHara M. 2005. Hybrid origins and $\mathrm{F} 1$ dominance in the free-floating sterile bladderwort, Utricularia australis f. australis (Lentibulariaceae). Amer. J. Bot. 92: 469-476.

KäSermann C. \& Moser D. M. 1999. Fiches pratiques pour la conservation - Plantes à fleurs et fougères. OFEFP, Bern.

KISH R. YA. \& DANILIK I. M. 2009. Pukhirnik brema Utricularia bremii Heer (U. minor L. subsp. bremii (Heer) Nyman). In: YA. P. DidukH (ed.), Chervona Kniga Ukraini, p. 514. Roslinnij Svit, Kiiv.

Kölliker A 1839. Verzeichnis der Phanerogamischen Gewächse des Cantons Zürich. Druck von Orell, Füssli \& Co., Zürich.

Kosiba P. 2004. Chemical properties and similarity of habitats of Utricularia species in Lower Silesia, Poland. Acta Soc. Bot. Poloniae 73(4): 335-341.

KraJewski Ł. 2011. Cladietum marisci association in Dąbrowa Górnicza sand pit against background of Great Fen-sedge Cladium mariscus occurence in Poland. Chrońmy Przyr. Ojczysta 67(3): 276-283 (in Polish with English summary).

KrajewsKi Ł. 2012. Stoneworts (Characeae) of Zagłębie Dąbrowskie (S Poland). Natura Silesiae Superioris 13: 13-56 (in Polish with English and German summaries).

ŁAWRYNOWICZ J. 1965. Lobelia lakes in East and North-Eastern part of Chojnice County. Badan. Fizjogr. Polsk. Zachodn., $B$ 16: 195-198 (in Polish).

LETTAU A. 1911. Floristische Untersuchungen im Kreise Rössel und in Teilen angrenzender kreise in Sommer 1910. Jahresbericht des Preußischen Botanischen Vereins [1910]: $17-25$.

Matuszkiewicz W. 2007. Przewodnik do oznaczania zbiorowisk roślinnych Polski. Vademecum Geobotanicum 3. Wydawnictwo Naukowe PWN, Warszawa.

Mirek Z., PięKoś-Mirkowa H., ZająC A. \& ZająC M. 2002. Flowering plants and pteridophytes of Poland. A checklist. Polish Academy of Sciences, W. Szafer Institute of Botany, Kraków.

Moravec J. 1995. Red list of plant communities of the Czech Republic and their endangerment. Ed. 2. Severočes. Přir. Suppl.: 1-206 (in Czech with English summary).

PŁachno B. J. 2008. Utricularia australis - species rare or common in Upper Silesia? Przyroda Górnego Ślaska 54: 12-13 (in Polish).

Rahmann O. U., Adamec L. \& Katsuhiko K. 2001. Chromosome numbers of Utricularia bremii and Utricularia dimorphanta (Lentibulariaceae). Chromosome Science 5: 105-108.

Schube T. 1903. Die Verbreitung der Gefäßpflanzen in Schlesien preußischen und österreichischen Anteils. Druck von R. Nischkowsky, Breslau.

SCHUBE T. 1904. Flora von Schlesien preußischen und österreichischen Anteils. Verlag von Wilh. Gottl. Korn, Breslau.

TAYLOR P. 1989. The genus Utricularia - a taxonomic monograph. Kew Bull., Addit. Ser. 14: 1-734.

Vydrová A., Grulich V., Ekrt L. \& Ekrtová E. 2009. Řídká blana near Zahájí (South Bohemia) - a significant locality of aquatic and marsh flora and vegetation. Muzeum a Současnost, Roztoky, Seriae Naturae 24: 27-54 (in Czech with English summary).

Żukowski W. 1974. Distribution of the species of the genus Utricularia L. in Poland. Badan. Fizjogr. Polsk. Zachodn., $B$ 27:189-217 (in Polish with English summary). 